\title{
ENVIRONMENTAL PERCEPTION AS A TOOL TO PREDICT PRO- ENVIRONMENTAL ACTIONS
}

\author{
Mirlaine Rotoly de Freitas ${ }^{1}$ \\ Renato Luiz Grisi Macedo² \\ Matheus Puggina de Freitas ${ }^{3}$
}

\begin{abstract}
Environmental perception may have different levels of complexity, which have been related to the meaningfulness of pro-environmental actions. Environmental perceptions can be captured using different approaches, with particular emphasis in this work on drawings about environment and intensity rulers. This method can be applied to e.g. students and farmers in order to understand their stage of environmental awareness, as well as to predict the category of their possible pro-environmental actions. Teaching routines can be traced from these outcomes to improve the efficacy of pro-environmental actions in the short, medium and/or long term. The method is concisely described in this work and has been applied in a collection of case studies reported by us elsewhere, in order to capture the environmental perception as a tool to predict the meaningfulness of pro-environmental actions.
\end{abstract}

Keywords: Environmental perception; Environmental complexity; Socioecological system.

\footnotetext{
1 Department of Chemistry, Federal University of Lavras, Lavras, MG, Brazil. E-mail: mrotoly@gmail.com

2 Department of Forest Sciences, Federal University of Lavras, Lavras, MG, Brazil.

E-mail: rlgrisi@dcf.ufla.br

${ }^{3}$ Department of Chemistry, Federal University of Lavras, Lavras, MG, Brazil. E-mail: matheus@dqi.ufla.br
} 
Resumo: A percepção ambiental possui diferentes níveis de complexidade, os quais estão relacionados com o grau de ações pró-ambientais. As percepções ambientais podem ser obtidas de diversas maneiras, com ênfase particular, neste trabalho, em desenhos sobre meio ambiente e réguas de intensidade. Esses métodos podem ser aplicados em, por exemplo, estudantes e agricultores, com o intuito de compreender o seu estágio de concepção ambiental, bem como para prever a categoria de suas prováveis ações próambientais. Práticas de ensino podem ser traçadas a partir desses resultados para tornar as ações pró-ambientais mais eficazes no curto, médio e longo prazo. O método é concisamente descrito neste trabalho e tem sido aplicado em alguns estudos de caso reportados pelos autores em outros meios de comunicação, com o objetivo de capturar a percepção ambiental, como uma ferramenta de previsão do grau de significância das ações pró-ambientais.

Palavras-chave: Percepção ambiental; Complexidade ambiental; Sistema socioecológico.

\section{Introduction}

This work reports methodologies to confirm the correlation between environmental perception and pro-environmental actions, since we have been finding for many years clear evidences that those having deeper awareness (more complex view) on environment tend to develop more meaningful proenvironmental actions. In this context, the environmental perception can e.g. be captured by means of drawings representing environment, according to the individual's personal conception. Both environmental perception and the prospective pro-environmental actions to be developed by a given individual can be collected in a questionnaire, which is analyzed on the basis of theories and the ways succinctly described as follows.

\section{Views and development in environmental perception}

The term sustainability has gained widespread use since 1992, after the United Nations Conference on Environment and Development. This term is connected to socio-ecological system (KRASNY et al., 2010) and resilience thinking (FAZEY et al., 2010), which account for the complexity of the environment, by considering the interrelationships of the maximum number possible of environmental elements, both natural and anthropogenic (LEFF, 2003). Overall, the human being plays a fundamental role within the concept of environmental complexity, as emphasized in the ONU's report of the high-level panel on global sustainability in 2012 entitled "Resilient people, resilient planet: A future worth choosing". The sustainable use of natural resources can be achieved if people feel responsible and part of the environment, as well as connected to it. This feeling can be strengthened using teaching methodologies supported by theories based on socio-ecological system and resilience thinking, 
which can be developed upon analysis of the environmental awareness of a given target population. Since farmers and students engaged with the agricultural science field have direct contact with land, nature and human transformations, it is worth studying their environmental perception in order to evaluate their (either positive or negative) impact on the environment. However, primary level students are also an important target to evaluate the status of environmental complexity at an early stage of learning.

The environmental perception of students in primary and higher education has been shown to be related to different categories of proenvironmental actions, from little to highly meaningful actions (FREITAS et al., 2014). These actions are classified (from little to highly meaningful) as sensibility, comprehension, responsibility and competence \& citizenship proenvironmental actions. While sensibility actions reflect a preliminary alert process to achieve the systemic thinking in environmental education (e.g. to demand monitoring from police, politicians or decision-makers), competence \& citizenship actions reflect the ability to evaluate and strongly act on the environment, promoting an ethics capable of conciliating the elements of the system (e.g. to promote the biodiversity conservation). Comprehension (e.g. to participate in courses about environmental issues) and responsibility (e.g. to separate materials for recycling) actions are a middle ground in terms of meaningfulness.

\section{Method development and prospective results}

The relationship between environmental perception (PERC) and the prospective pro-environmental actions (PEA) is established by analyzing how the former (PERC) varies with respect to the latter (PEA), using principal component analysis - PCA. In practice, a data matrix with $m$ rows (students) should be built with $n$ columns, corresponding to the scores in environmental perception and the categories of pro-environmental actions. These outcomes are obtained from a questionnaire, where students are asked to draw the meaning of environment and to describe the most effective pro-environmental action (the categorization into the classes above should take into account the concepts of resilience and socio-ecological system). Such a description should be discursive rather than chosen from multiple alternatives, in order to obtain the expected relationship between environmental perception and proenvironmental actions of Figure 1. Otherwise, such a relationship may not be found (FREITAS et al., 2015a).

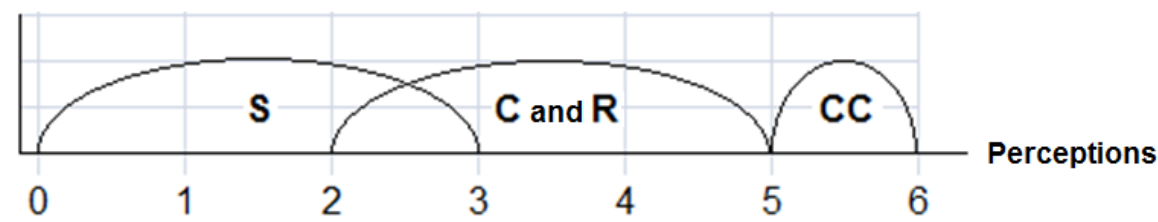

Figure 1: Relationship between the level of environmental perception (0 to 6$)$ and categories of pro-environmental actions. $\mathbf{S}=$ sensibility; $\mathbf{C}=$ comprehension; $\mathbf{R}=$ responsibility; $\mathbf{C} \mathbf{C}=$ competence \& citizenship.

Revbea, São Paulo, V. 11, № 1: 355-360, 2016.

revista brasileira

educação ambiental 
The scores of environmental perception are obtained assuming one point to elements referring to flora, fauna, other natural elements and artificial elements, and two points to human being/activities, summing up a maximum of six points. For instance, an environment drawing described only as a tree would be scored with one (1) point, while a complex drawing, including vegetation, animals, river, buildings and people would be scored with six (6) points. The relationship of the overall scores with the type of pro-environmental action can be performed using multivariate statistics, e.g. principal component analysis. An ideal PCA scenario would show the vector relative to the environmental perception variable closest to the competence \& citizenship variable, followed by responsibility, comprehension and sensibility, since higher environmental perception scores are expected to be achieved by those mentioning competence \& citizenship actions, while lower environmental perception scores tend to be characteristic of those mentioning sensibility actions (Figure 2). Since such a relationship has been nearly confirmed to a variety of students (from primary to higher education, and from general to agricultural science undergraduates) (FREITAS, 2014), their environmental perception can indeed be checked using drawings and the corresponding pro-environmental actions can be extrapolated from that relationship. The improvement of the environmental perception and, prospectively, of pro-environmental actions, upon teaching activities related to environmental complexity, socio-ecological system and resilience thinking (preferably if connected with previous knowledge and life experience), can be monitored by applying questionnaires continuously. These ongoing questionnaires should provide updated information about the students' environmental knowledge in order to fit the teaching activities to their actual needs.
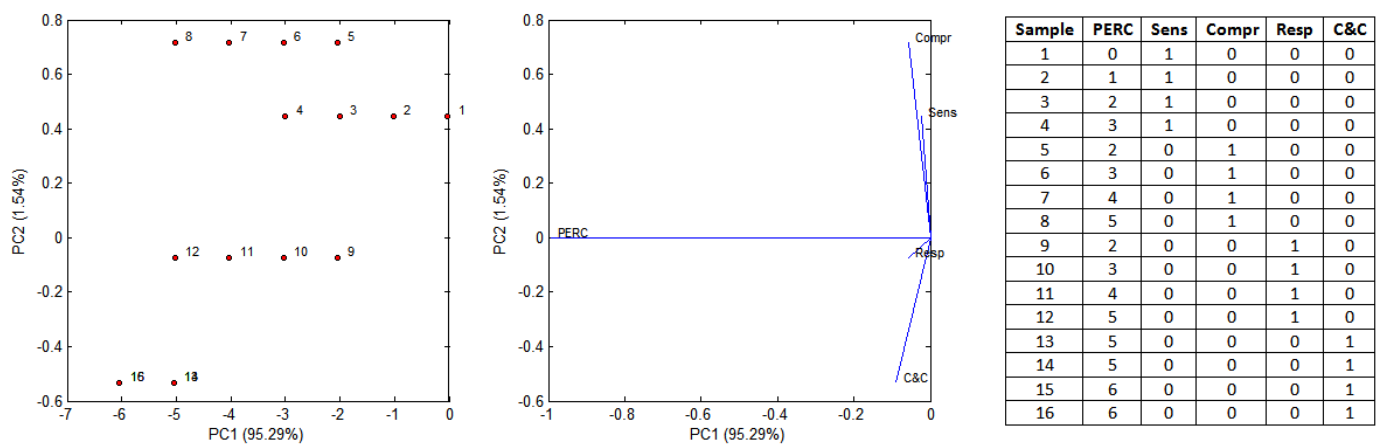

Figure 2: Virtual scenario of a principal component analysis (PCA) including environmental perception and pro-environmental actions as variables in the data matrix. The scores plot represents the coordinates in $\mathrm{PC} 1 \times \mathrm{PC} 2$ of each answerer (sample). The loadings plot indicates how each variable contributes to cluster the samples according to the scores plot. The exemplified matrix used to build the PCA is shown, containing the environmental perception scores (from 0 to 6 ) and 0 or 1 for each remaining variable (1 indicates the category of action indicated by the answerer), according to the proposed scheme of Figure 1. See that, in PC1 (which explains $95.2 \%$ of data variance), PERC (environmental perception) is closest to C\&C (competence and citizenship), followed by Resp (responsibility) and Compr (comprehension), and lastly to Sens (sensibility), because the environmental perception scores decrease nearly in this order.

Revbea, São Paulo, V. 11, № 1: 355-360, 2016. 
In the non-formal learning, as an extension activity, intensity rulers can be used e.g. to investigate the importance given by farmers to price, efficacy and environment when choosing an agrochemical to be used in their crops (FREITAS et al., 2015b). These can be intensity rulers ranging from 0 (nothing important) to $10 \mathrm{~cm}$ (totally important) for each item (price, efficacy and environment), and the answerer should simply mark with a risk, from 0 to 10 $\mathrm{cm}$, how intense is his/her concern about each item when purchasing an agrochemical substance. This tool can be quickly applied during a working day to obtain the level of preoccupation about environmental issues, which is proportional to the environmental perception. Depending on the outcomes of this analysis (more or less complex perception), reflexive discussion about food safety and environmental management can be performed during rural extension activities with the support of the aforementioned environmental theories. In other words, this teaching strategy is hopefully capable of providing farmers with the planning of environmental conservation in the medium and long term, in accordance to the resilience principles.

\section{Conclusions}

The environmental perception of students reflects their prospective proenvironmental actions; people with highly complex environmental perception would probably yield more meaningful pro-environmental activities. Thus, improvement of the environmental conception, on the basis of socio-ecological system and resilience thinking, tends to benefit a sustainable environment. Teaching activities focusing on the interrelationship among elements, the personal role of each individual within the environment, and their responsibility to environmental changes, are expected to increase the level of environmental complexity, which can be checked with ongoing applications of the proposed questionnaire. In the non formal education, e.g. to farmers, education strategies emphasizing socio-ecological resilience and old-knowledge, are expected to encourage the empowerment and consequent dissemination of sustainable and cleaner practices of production.

\section{ACKNOWLEDGEMENTS}

Authors are grateful to Fundação de Amparo à Pesquisa do Estado de Minas Gerais (FAPEMIG) for the financial support of this research, as well as to Coordenação de Aperfeiçoamento de Pessoal de Nível Superior (PNPD/CAPES, Rede Mineira de Química to M.R.F.) and Conselho Nacional de Desenvolvimento Científico e Tecnológico (CNPq, to R.L.G.M. and M.P.F.) for the fellowships. 


\section{References}

LEFF, E. A. Environmental complexity. São Paulo: Cortez, 2003.

FAZEY, I. Resilience and higher order thinking. Ecol. Soc., Wolfville, v. 15, n. 3, 9, 2010.

KRASNY, M. E.; LUNDHOLM, C.; PLUMMER, R. Resilience in social-ecological systems: the roles of learning and education. Environ. Edu. Res., London, v. 16, n. 5-6, 463-474, 2010.

FREITAS, M. R. Metodologias em educação ambiental formal e não formal para a conservação do sistema socioecológico. 2014. 182f. Tese (Doutorado em Engenharia Florestal) - Curso de Pós-Graduação em Engenharia Florestal, Universidade Federal de Lavras. Disponível em <http://repositorio.ufla.br/handle/1/4628>. Acesso em 12 mar. 2016.

FREITAS, M.R.; MACEDO, R.L.G.; FREITAS, M.P.; NUNES, C.A.; VENTURIN, $\mathrm{N}$. Environmental perception as a diagnostic probe of environmental complexity levels. J. Agric. Edu. Ext., London, v. 21, n. 2, 149-158, $2015 a$.

FREITAS, M.R.; MATIAS, S.V.B.; MACEDO, R.L.G.; FREITAS, M.P.; VENTURIN, N. Non-formal Environmental Education: A Case Study with Farmers in a Town of the South Minas Gerais State, Brazil. Chin. J. Pop. Res. Environ., London, v. 13, n. 4, 324-331, 2015b. 